\title{
The Role of Competitive Strategies in the Effect of Entrepreneurial Mindset and the Entrepreneurial Leadership on Business Performance*
}

\author{
Göknur Ersarı1 $\odot$, Atılhan Naktiyok² $₫$
}

\begin{abstract}
The main purpose of this study is to examine the role of cost leadership and differentiation strategies in the relationships among entrepreneurial leadership, entrepreneurial mindset, and business performance. The sample of the study consists of 443 managers working in 8 sectors affiliated to the Erzurum Chamber of Commerce and Industry. The data were collected with the help of a survey consisting of Entrepreneurial Leadership Scale developed by Renko et al. (2015), Entrepreneurial Mindset Scale developed by Mathisen and Arnulf (2014), Competitive Strategies Scale developed by Espino-Rodríguez and Lai (2014), and Business Performance Scale adapted to Turkish by Zehir (2016). The data were analyzed by structural equation modeling. According to the research findings, while entrepreneurial mindset has a positive effect on entrepreneurial leadership and business performance; it has been determined that it has no significant effect on cost leadership and differentiation strategies. However, entrepreneurial leadership has a positive effect on business performance, cost leadership, and differentiation strategies. Also, it was concluded that cost leadership and differentiation strategies should not be used together..
\end{abstract}

\section{Keywords}

Entrepreneurial Leadership, Entrepreneurial Mindset, Cost Leadership Strategy, Differentiation Strategy, and Business Performance

\section{Introduction}

With the development of technology and increasing competition, the business environment has changed rapidly and has become complicated. Increasing the performance and continuity of the businesses depends on their perception of environmental changes and developing strategies suitable for these changes. In this context, there is a need for entrepreneurial leaders and entrepreneurial mindset that can direct the organization and employees to perceive the developments and changes in the economic and technological fields in recent

\footnotetext{
*This study is derived from Göknur Ersarı's doctoral thesis with Reference Number (10075778).

1 Corresponding Author: Göknur Ersarı (Dr.), Nevşehir Hacı Bektaş Veli University, Faculty of Economics and Administrative Sciences, Department of Business Administration, Nevşehir, Turkey. E-mail: gersari@nevsehir.edu.tr ORCID: 0000-0001-8380-6832

2 Atilhan Naktiyok (Prof. Dr.), Atatürk University, Faculty of Economics and Administrative Sciences, Department of Business Administration, Erzurum, Turkey. E-mail: anakti@atauni.edu.tr ORCID: 0000-0001-6155-5745

To cite this article: Ersari, G., \& Naktiyok, A. (2021). The Role of Competitive Strategies in the Effect of Entrepreneurial Mindset and the Entrepreneurial Leadership on Business Performance. Istanbul Business Research. Advanced Online Publication. http://doi.org/10.26650/ibr.2022.51.834294
} 
years. However, there is a limited number of studies on both entrepreneurial leadership and entrepreneurial mindset.

It is important whether competitive strategies can play an effective role in the impact of entrepreneurial leadership and entrepreneurial mindset on business performance, especially in a business environment dominated by chaos and complexity. As competition is intense in today's business world, managers need to determine the right strategies. In this context, there is a need for an innovative, entrepreneurial, visionary, and bold leader model that can adapt to the conditions required by age. Entrepreneurial leaders have the ability to determine the best strategies suitable for today's global economy with their entrepreneurial features and strategic perspectives. These leaders are people who can provide a competitive advantage to the company through their entrepreneurial activities. Because entrepreneurial leaders have the capacity to evaluate the entrepreneurial opportunities that will give the company a competitive advantage.

Another important issue emphasized in the research is that there are two different views in the literature on whether cost leadership and differentiation strategies can be applied simultaneously. While Porter (1985) has argued that businesses should choose and implement only one of their generic strategies (cost leadership and differentiation strategy) to improve their performance; Hill (1988) and Murray (1988) have argued that cost leadership and differentiation strategies are strategies that can be used together.

In this study, the literature was examined and answers to the following questions were sought. How and in what way do the entrepreneurial mindset and the entrepreneurial leadership affect the business performance? Does this impact change if a business adopts cost leadership and differentiation strategies? Can businesses use cost leadership and differentiation strategies together? Based on the findings found in previous studies, the hypotheses of the research have been developed and then research has been conducted on managers working in 8 sectors of the Erzurum Chamber of Commerce and Industry to test the research model and hypotheses. Accordingly, the aim of the research is to reveal the mediating role of cost leadership and differentiation strategy, in the effect of the entrepreneurial mindset and entrepreneurial leadership on business performance. It is also to determine whether cost leadership and differentiation strategies can be used together.

\section{Theoretical Explanations}

\section{Entrepreneurial Mindset}

Entrepreneurial mindset is the accumulation of knowledge that provides the advantage of instant decision-making to adapt quickly to environmental changes that are not foreseen in an organization (Antoncic \& Hisrich, 2004: 521). Ireland et al. defined entrepreneurial mindset 
as a growth-oriented perspective that encourages individuals to wards flexibility, creativity and continuous innovation (Ireland et al., 2003: 968). Entrepreneurial mindset focuses on identifying and evaluating opportunities (Obeng et al., 2014: 503). Therefore, entrepreneurial mindset is a way of thinking that provides a competitive advantage to businesses, especially in environments where the speed of competition and change is high.

Entrepreneurial mindset, which is important for managers and employees as well as individual entrepreneurs, is a set of creative thoughts that contribute to the development of society (Ireland et al., 2003: 967). These creative ideas contribute to the development of society after the industry. In this context, it is important to institutionalize the entrepreneurial mindset as an essential element of entrepreneurial and strategic management in businesses (McGrath $\&$ MacMillan, 2000). As a result, the entrepreneurial mindset is a series of thoughts developed by businesses or individuals in terms of capturing opportunities and taking advantage of these opportunities in uncertain environments where change is very fast.

According to McGrath and MacMillan (2000), the entrepreneurial mindset is a way of thinking that exists in businesses that see uncertainty as an advantage. Businesses with an entrepreneurial mindset successfully overcome uncertainty and perform better (Roomi and Harrison, 2011: 23). Besides, the entrepreneurial mindset ensures the growth of the business with its competitive advantage and contributes to the development and growth of the country's economy (Ireland et al., 2003: 968).

\section{Entrepreneurial Leadership}

Entrepreneurial leadership refers to the process of contributing to the firm by constantly creating value within the firm and improving the skills of the employee (Gupta et al., 2004: 243). Ireland et al. (2003: 977) described entrepreneurial leadership as the ability to influence others to manage resources strategically. According to Thornberry (2006), entrepreneurial leadership includes inspiring others, ambition, vision, capturing and developing new business opportunities.

Entrepreneurial leaders are individuals who help employees for the development of the organization and focus on new opportunities and new solutions (Darling \& Beebe, 2007: 78). Renko (2015) states that entrepreneurial leadership enables to influence and manage the performance of group members by realizing and benefiting from entrepreneurial opportunities to achieve organizational goals (Renko et al., 2015: 55). Entrepreneurial leaders are creative people who can see opportunities that others cannot see (Zijlstra, 2014: 13).

\section{Business Performance}

Performance is a tool to evaluate whether an individual or organization is using resources effectively (Lee et al., 2001). Performance is often defined as measuring the contribution of 
members of the organization to the organization's goals (Zhang, 2012: 16). Business performance refers to the ability of an organization to achieve its goals by using its resources effectively and efficiently (Daft, 2010: 9). Therefore, business performance measures organizational success and shows how efficiently and effectively the organization uses scarce resources to achieve organizational goals (Iqbal et al., 2018).

Business performance, on the other hand, shows the extent to which an organization has achieved its market and financial goals (Chavez et al., 2017: 33). Overall, business performance is a measurement tool that shows the extent to which an organization has achieved its goals through the use of all its assets, including human, physical and capital resources (Iqbal et al., 2018).

\section{Competitive Strategies}

There are three basic competitive strategies developed by Porter in the literature. These are cost leadership, differentiation strategy, and focus strategy. In this study, cost leadership and differentiation strategies, which are more commonly used strategies, were included. The reason for this is that the research focused on the difference of opinion as to whether cost leadership and differentiation strategy can be used together.

\section{Cost Leadership Strategy}

Cost leadership strategy means that the company produces and sells similar goods or services at a lower cost than its competitors (Naktiyok, 2016). A company that applies a cost leadership strategy focuses on gaining a competitive advantage by producing a lower-cost product than its competitors without falling below the standard quality level (Barney \& Hesterly, 2012: 122). The company that follows this strategy aims to be the company that produces the lowest cost goods or services in the industry (Bordean et al., 2010: 174). The company, which is the cost leader by producing low-cost products, can achieve a satisfactory profit even if it sells its products at a lower price than its competitors (Liu et al., 2018: 5).

Cost leadership is a strategy that emphasizes producing low-cost standard products per unit for price-sensitive consumers (David and David, 2016). A company that implements cost leadership must first establish its production areas and facilities based on economies of scale (Linton and Kask, 2017: 169). Subsequently, it is important to minimize costs in areas such as R\&D, service, sales force and advertisements. At this point, the experiences of the companies will contribute to the reduction of costs significantly (Dinçer, 2013: 200).

\section{Differentiation Strategy}

Differentiation strategy is a competitive strategy that allows a price above the average 
price level in the market by adding a number of new features to products or services (Barney and Hesterly, 2012: 150). A company that applies a differentiation strategy aims to be unique in the eyes of its customers (Ortega, 2010: 1275). Thus, the company may request higher prices for its product. (David and David, 2016: 136).

The differentiation strategy aims to create brand loyalty by making small innovations in the product. With the creation of brand loyalty, the price sensitivities of customers can be reduced and thus increasing costs can be transferred to customers (Kavale et al., 2016). The company, which wants to take advantage of the differentiation strategy, uses elements such as product design, quality, ease of use, speed, and flexibility to meet customer demands (Linton and Kask, 2017: 169). Thus, these companies can gain a competitive advantage thanks to the innovations they apply to their products or services.

\section{Development of Hypotheses}

\section{The Relationship Between Entrepreneurial Mindset and Entrepreneurial Leadership}

Entrepreneurial leaders are people engaged in entrepreneurial activities, capturing opportunities and leading innovation. With the increasing competition, businesses need managers who think entrepreneurial and exhibit entrepreneurial leadership behaviors to ensure their continuity. According to Newman (2013), students should be taught entrepreneurial mindset and entrepreneurial leadership at universities.

According to the model developed by Ireland et al. (2003), entrepreneurial mindset and entrepreneurial leadership affect each other mutually. Similarly, the model developed by Lassen (2007) shows that entrepreneurial mindset and entrepreneurial leadership indirectly affect each other. In the model developed by Altuntaş (2010), it is assumed that entrepreneurial mindset and entrepreneurial leadership affect each other mutually; however, as a result of the analyzes, a new model had to be developed since there was a problem of multiple linearities between these two variables in his study. As a result, an entrepreneurial mindset can affect the behavior of entrepreneurial leaders.

Based on the above studies, we have predicted that entrepreneurial mindset will have a significant impact on entrepreneurial leadership, and therefore we have developed the $\mathrm{H} 1$ hypothesis.

H1: Managers' entrepreneurial mindset has a significant and positive effect on their entrepreneurial leadership behaviors. 


\section{The Relationship Between Entrepreneurial Mindset and Business Performance}

The relationship between entrepreneurship and business performance has been the subject of many studies. As a result of many of these studies, entrepreneurship-themed issues have been found to have a positive effect on organizational performance (Covin and Slevin, 1991; Zahra and Garvis, 2000; Lee et al., 2001; Rauch et al., 2009). Based on these studies, it is estimated that entrepreneurial mindset, one of the important issues of entrepreneurship, will have a positive effect on performance.

As a result of his research, Kimuli (2011) found that there is a positive and significant relationship between performance and entrepreneurial mindset, entrepreneurial personality traits, entrepreneurial leadership, strategic orientation, and entrepreneurial orientation. Neneh (2012) conducted research to identify the entrepreneurial mindset of small and medium-sized enterprises (SMEs) in South Africa and it was stated that the performances of entrepreneurial mindset organizations increased. Similarly, Njeru (2012) reported in his study that entrepreneurial mindset has a significant impact on performance.

Based on the above studies, it can be considered that an entrepreneurial mindset will have a direct positive effect on business performance.

H2: Managers' entrepreneurial mindset has a significant and positive effect on business performance.

\section{The Relationship Between Entrepreneurial Mindset and Competitive Strategies}

Firms should follow entrepreneurial strategies in a competitive environment. Because firms that determine strategies from an entrepreneurial perspective will be able to gain a competitive advantage (Miles et al., 2000). Research conducted in recent years has shown that an entrepreneurial mindset is necessary for successful entrepreneurial activities (Kimuli, 2011). One of the important features of entrepreneurs is that they perceive uncertain environments as opportunities. Therefore, an entrepreneurial mindset can provide companies with a competitive advantage (Miles et al., 2000). As a result of their research, Kriewall and Mekemson (2010) reported that entrepreneurial mindset is an important factor in producing new products.

Managers' entrepreneurial thinking skills will be effective in determining and implementing the best and most correct strategies in uncertain environments. Thus, managers' entrepreneurial thinking skills are expected to have a significant impact on competitive strategies.

H3: Managers' entrepreneurial mindset has a significant and positive effect on the cost leadership strategy.

H4: Managers' entrepreneurial mindset has a significant and positive effect on the differentiation strategy. 


\section{The Relationship Between Entrepreneurial Leadership and Business Performance}

Entrepreneurial leaders direct the innovation process and innovation performance especially in SMEs (Fontana et al., 2017). Mgeni and Nayak (2015) showed that there is a strong positive relationship between entrepreneurial leadership and business performance in their study. Chheda and Banga (2013) conducted a study on SMEs in India and found that variables such as continuous improvement, proactivity, innovation, and resource allocation have a positive effect on performance. Fontana et al. (2017) examined the relationships among entrepreneurial leadership, innovation process, and innovation performance within the scope of innovation management, and the results showed a positive relationship between entrepreneurial leadership and innovation process. Kesidou and Carter (2014) stated that entrepreneurial leadership will have a positive impact on firm performance and growth.

Entrepreneurial leaders are people who can take risks, are brave, agile, perceive opportunities, and have entrepreneurial alertness. These people have an important role in determining the strategies of companies and increasing their performance. It is very important for organizations to make the right decisions at the right time in environments where competition is intense and uncertainty and risk is high. Entrepreneurial leaders who can make the right decisions will contribute to increasing the performance of the organization. In light of these opinions, it is predicted that the entrepreneurial leadership behaviors of the managers will have a positive effect on the performance of the company.

H5: Managers' entrepreneurial leadership behaviors have a significant and positive effect on business performance.

\section{The Relationship Between Entrepreneurial Leadership and Competitive Strategies}

Entrepreneurial leaders play an important role in determining the right strategies for a firm's growth and profitability. (Leitch and Volery, 2017). In the study of Ling and Jaw (2011), it has been determined that entrepreneurial leadership has a positive effect on global competitiveness indirectly. Bagheri and Akbari (2017) revealed that entrepreneurial leadership has a significant and positive effect on the innovative behavior of nurses in their research. Newman et al. (2017) stated that entrepreneurial leaders have a positive effect on innovative behavior. Bagheri (2017) showed that entrepreneurial leadership has a positive impact on seeking opportunities and innovative behavior.

Entrepreneurial leaders are brave leaders who are not afraid to take risks (Currie et al., 2008: 3). Entrepreneurial leaders determine the right strategies in an uncertain environment, as they perceive turbulent environments as an opportunity. At this point, managers who can exhibit entrepreneurial leadership behavior can determine the right strategies at the right time. Therefore, it can be thought that the entrepreneurial leadership behaviors of the managers will play a determining role in the competitive strategies. 
H6: Managers' entrepreneurial leadership behaviors have a significant and positive effect on determining cost leadership strategy.

H7: Managers' entrepreneurial leadership behaviors have a significant and positive effect on determining differentiation strategy.

\section{The Relationship Between Competitive Strategies and Business Performance}

There are two different views in the literature on the use of cost leadership and differentiation strategies. The first of these views is that it is inconvenient to apply these two basic strategies together. For this reason, one of the most appropriate of these strategies should be chosen and applied. According to Porter (1980-1985), companies need to choose one of the cost leadership and differentiation strategies to be successful in the long run (Panwar et al., 2016: 579). Because cost leadership and differentiation strategies conflict when they are used together. The reason for this conflict is that differentiation is usually a costly strategy. According to Miller, the cost leadership strategy is incompatible with innovation (Linton and Kask, 2017: 170). Also, Kumar et al., (1997) and Thornhill et al. (2007), as a result of their research, found that organizations that use a single competitive strategy are more profitable than the organizations that use these strategies together. Josiah and Nyagara (2015) also gave an opinion that the cost leadership strategy may negatively affect innovation-business performance.

The second view on the use of cost leadership and differentiation strategies is that, contrary to Porter's view, both of these strategies are compatible strategies and can be successfully applied together. Some researchers, such as Hill (1988) and Murray (1988), have argued that differentiation and cost leadership strategies are not opposite strategies, rather they are compatible strategies and should be used together (Li and Li, 2008: 1-2). When the literature is examined, it is seen that there are many studies that support the use of two strategies together, at least in some cases (Phillips et al., 1983; Beal and Yasai-Ardekani, 2000; Spanos et al., 2004). On the other hand, Li and Li (2008) have reported that the performances of companies that use differentiation and cost leadership strategies both separately and together are positively affected.

Yamin et al. (1999) stated in their study that the companies performing medium level cost leadership increased their financial performance and the companies applying medium level differentiation strategy increased their organizational performance. Gyampah and Acquaah (2008) could not find a direct relationship between competitive strategies and firm performance. Teeratansirikool et al. (2013) determined that competitive strategies positively affect firm performance, and Ortega (2010) found that there was a positive relationship between cost leadership-differentiation strategies and performance.

Therefore, it is predicted that competitive strategies will have a significant impact on business performance and the following hypotheses have been developed. 
H8: Cost leadership strategy has a significant and positive effect on business performance.

H9: Differentiation strategy has a significant and positive effect on business performance.

\section{Materials and Methods}

Strategic entrepreneurship literature advocates that businesses should use entrepreneurship and strategic activities together to gain a competitive advantage (Ireland et al., 2003). In this research, a model is designed that shows the role of cost leadership and differentiation strategies in the effects of the entrepreneurial mindset and entrepreneurial leadership on business performance. Thus, a different combination of entrepreneurial and strategic activities is tried to be obtained. It is hoped that this study will contribute to the literature in terms of presenting a different combination and giving a new idea.

Another important issue emphasized in the research is that there are two different views in the literature on whether cost leadership and differentiation strategies can be applied simultaneously. First, Porter (Cited by Panwar et al., 2016: 579) and some other researchers, Miller (Cited by Linton and Helmet, 2017: 170), Thornhill (2007), Kumar (1997), Josiah and Nyagara (2015) argue the view that businesses should choose and implement only one of their generic strategies (cost leadership and differentiation strategy) to improve their performance. On the other hand, Hill (1988) and Murray (1988) believe that cost leadership and differentiation strategies are strategies that can be used together. Li and Li (2008) argue that when these two strategies are applied both together and separately, they increase the business performance.

In this research, it is aimed to determine whether cost leadership and differentiation strategies can be used together. Therefore, the focus strategy is not included in the model. Also, another aim of the research is to reveal the role of cost leadership and differentiation strategies in the effect of the entrepreneurial mindset and entrepreneurial leadership on business performance.

It is aimed to apply the research in a suitable sample where the variables in the model can be measured. Small and newly established entrepreneurial businesses are relatively skilled at identifying entrepreneurial opportunities, while they are less skilled at maintaining competitive advantage. Besides, large businesses are more capable of maintaining their competitive advantage while they are less capable of capturing opportunities. For this reason, newly established small businesses tend to seek opportunities, while large businesses tend to seek competitive advantages (Ireland et al., 2003: 967). In this context, it is predicted that it would be more beneficial to select the sample of the research among medium-sized businesses to evaluate both entrepreneurial and strategic situations at the same distance. 


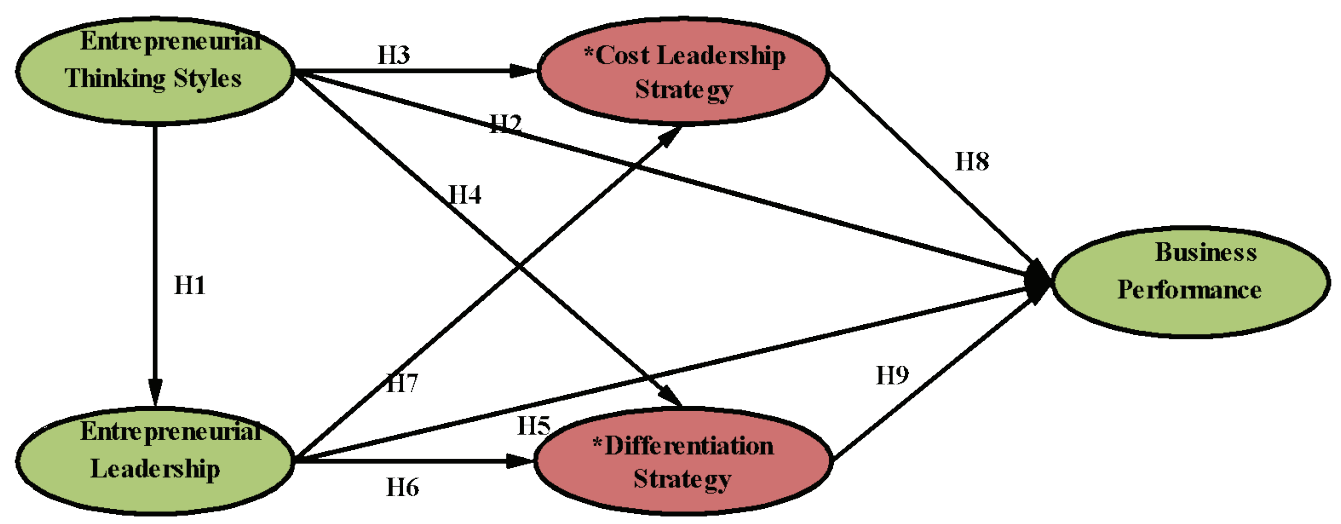

Figure 1. Model Of The Study

The universe of the research consists of the founders or managers of 1473 medium-sized businesses operating in eight sectors (furniture, construction, auto spare parts, auto sales, markets, textiles, bakery sellers, training courses) in Erzurum-2017. The sample size selected from the universe of this research was calculated as 305, within the confidence limits of 95\%, with an error of 5\% (https://www.surveysystem.com/sscalc.htm) (Kurtulus, 2006). 500 surveys were distributed to businesses and 467 of these surveys were returned. However, 443 surveys were used in the study because 24 surveys were incorrect.

\section{Entrepreneurial Mindset Scale}

In this study, the entrepreneurial mindset (EMS) scale developed by Mathisen and Arnulf (2014) was used to measure the entrepreneurial thinking abilities of the managers. The scale consists of three dimensions: Elaborating mindset (EM), Implemental mindset (IM), Compulsiveness mindset (CM). There are 8 items about each dimension and the scale consists of 24 items in total.

As a result of the exploratory factor analysis, IM1, IM7, and CM1 items were removed from the scale because the factor loads of the items were less than 0.40 and exploratory factor analysis was repeated for 21 items. Then, it was observed that the factor loads of none of the 21-items scale were not less than 0.40 and that all items were collected under relevant factors. Besides, the three factors explained $60.569 \%$ of the total variance, KaiserMeyer-Olkin (KMO) value was 0.912, Bartlett's test of sphericity was significant (bartlett's test: 5367.089 $\mathrm{p}=0.000$ ) and Cronbach alpha value was 0.868 . Confirmatory factor analysis was also performed for the scale after the exploratory factor analysis. As a result of the analysis, three factors were linked to a single factor as an entrepreneurial mindset (EMS). All of the fit indices for the second level confirmatory factor analysis (CMIN/DF: 2.997; GFI: 0.895; AGFI: 0.867; NFI: 0.907; IFI: 0.936; TLI: 0.926; CFI: 0.936; RMSEA: 0.067; RMR: 0.046; SRMR: 0.057 ) are within the acceptable range. 


\section{Entrepreneurial Leadership Scale}

In this study, the entrepreneurial leadership scale developed by Renko et al. (2015: 67) was used to measure the entrepreneurial leadership skills of managers. The entrepreneurial leadership scale has one dimension and consists of 8 items. We have used the EL code for the entrepreneurial leadership variable. Item analysis, exploratory and confirmatory factor analysis were performed to ensure the validity and reliability of the scale.

As a result of the exploratory factor analysis, EL6 and EL7 items were removed from the scale. After exploratory factor analysis for six items was performed again, it was found that the single factor explained $45 \%$ of the total variance, $\mathrm{KMO}$ value was 0.757 , Bartlett's test of sphericity was significant (bartlett's test: $618.872 \mathrm{p}=0.000$ ) and Cronbach alpha value was 0.749 . Confirmatory factor analysis was performed after the exploratory factor analysis. As a result of the analysis, the EL8 item was removed from the scale because the standardized regression load of EL8 was less than 0.50 . The confirmatory factor analysis was performed again after EL8-item was removed from the scale. All the fit indices of the scale (CMIN/DF: 2.390; GFI: 0.991; AGFI: 0.968; NFI: 0.983; IFI: 0.990; TLI: 0.974; CFI: 0.990; RMSEA: 0.056; RMR: 0.019; SRMR: 0.024) are within acceptable limits.

\section{Competitive Strategies Scale}

The competitive strategies scale has two-dimension: cost leadership and differentiation strategies. The differentiation strategy dimension has 5 items and the cost leadership strategy dimension has 4 items. The scale consists of 9 items in total. We have used the DS code for the differentiation strategy variable and the CL code for the cost leadership in this study. The competitive strategy scale developed by Gilley and Rasheed (2000) and Acquaah et al (2008) was taken from the work of Espino-Rodríguez and Lai (2014) (Espino-Rodríguez and Lai, 2014: 14). Item analysis, exploratory and confirmatory factor analysis were performed to ensure the reliability and validity of the scale.

As a result of the item analysis, the total score correlation of the DS1 item was found to be less than 0.30 . Thus, the item was removed from the scale and the analyzes were repeated. Then, exploratory and confirmatory factor analysis were performed for 8 items. As a result of the exploratory factor analysis, the KMO value was 0.746 , and Bartlett's test of sphericity was significant (Bartlett's test: $1091.722 \mathrm{p}=0.000$ ). It was determined that the cost leadership strategy explained $30.5 \%$ of the total variance and that the Cronbach alpha value was 0.777 . It was also understood that the differentiation strategy explained $29.94 \%$ of the total variance and that the Cronbach alpha value was 0.766 .

Also, the confirmatory factor analysis showed that the regression load of the DS3 item was less than 0.50 and the item was removed from the scale since this value was not considered statistically significant. The confirmatory factor analysis was repeated after the item was 
removed from the scale. All of the fit indices for confirmatory factor analysis (CMIN/DF: 3.351; GFI: 0.971; AGFI: 0.938; NFI: 0.956; IFI: 0.969; TLI: 0.950; CFI: 0.969; RMSEA: 0.073; RMR: 0.042; SRMR: 0.048) are within acceptable limits.

\section{Business Performance Scale}

In the literature, it is emphasized that the financial, market, and innovation performances of the organization should be evaluated together in measuring the business performance (Keskin et al. 2016). For this reason, two different scales have been used to measure business performances. The first of these scales are related to the financial and market performances and consist of 12 items. The second scale is related to the innovation performance and consists of 7 items. The business performance scale (BP) consists of 17 items in total. Both scales were developed by Zehir (2016) based on the studies of researchers such as Zahra et al., Baker and Sinkula, Lynch et al., Prajogo and Sohal. Item analysis, exploratory and confirmatory factor analysis were performed to ensure the reliability and validity of the scales.

FMP code was used to indicate 12 items related to the Financial/Market Performance scale, and IP code was used to indicate 7 items related to the Innovation Performance scale. The Cronbach alpha value for the Financial/Market Performance scale was 0.960 and the Cronbach alpha value for the Innovation Performance scale was 0.947. As a result of exploratory factor analysis of the 19-item business performance scale, KMO value was 0.960 and Bartlett's test of sphericity was significant (Bartlett's test: 8304,453 and $\mathrm{p}=0.000$ ). The Cronbach alpha value of the business performance scale was 0.961. Also, the factor explained $72,446 \%$ of the total variance. Confirmatory factor analysis was performed after exploratory factor analysis. As a result of the confirmatory factor analysis, it was found that the regression load of any item was not less than 0.50 . In addition, all of the fit indices for confirmatory factor analysis (CMIN/DF: 4.644; GFI: 0.847; AGFI: 0808; NFI: 0.917; IFI: 0.934; TLI: 0.925; CFI: 0.933; RMSEA: 0.091; RMR: 0.028; SRMR: 0.0381) are within acceptable limits.

\section{Analysis and Findings}

The main statistical values and correlation coefficients for the variables in the study are shown in Table 1. When the correlation coefficients are examined, It has been observed that there is a positive and significant relationship between entrepreneurial leadership and entrepreneurial mindset $(\mathrm{r}=0.360)$, entrepreneurial leadership and cost leadership $(\mathrm{r}=0.112)$, entrepreneurial leadership and differentiation strategies $(\mathrm{r}=0.247)$, and entrepreneurial leadership and business performance $(\mathrm{r}=0.237)$. It has been observed that there is a positive and significant relationship between the entrepreneurial mindset and differentiation strategy $(\mathrm{r}=$ $0.154)$, the entrepreneurial mindset, and the business performance $(\mathrm{r}=0.103)$. Also, the cost leadership strategy negatively affected the business performance $(\mathrm{r}=-0.210)$; Differentiation 
strategy positively affected the business performance $(\mathrm{r}=0.248)$. It can be thought that this situation is caused by the innovation performance questions within the business performance.

Considering the average of the variables of the study, it is seen that the average of entrepreneurial leadership is high and the cost leadership strategy has a higher average than the differentiation strategy. According to these results, it can be said that the business managers participating in the research see themselves as entrepreneurial leaders and prefer cost leadership more than differentiation strategies.

Table 1

Relationship Between Variables

\begin{tabular}{lccccccc}
\hline & $\bar{X}$ & S.D. & $\mathbf{1}$ & $\mathbf{2}$ & $\mathbf{3}$ & $\mathbf{4}$ & $\mathbf{5}$ \\
\hline EL1 & 4.39 & 0.59 & 1 & & & & \\
EMS2 & 3.91 & 0.50 & $0.360^{* *}$ & 1 & & & \\
CL3 & 4.01 & 0.75 & $0.112^{*}$ & 0.055 & 1 & & \\
DS4 & 3.39 & 0.94 & $0.247^{* *}$ & $0.154^{* *}$ & $-0.241^{* *}$ & 1 & \\
BP5 & 3.68 & 0.65 & $0.237^{* *}$ & $0.103^{*}$ & $-0.210^{* *}$ & $0.248^{* *}$ & 1 \\
\hline
\end{tabular}

The path coefficients and the variance parameter values among the variables of the structural model are shown in Figure 2 and the estimation results for the model are shown in Table 2.

When Figure 2 and Table 2 are examined together, the relationships between entrepreneurial mindset and entrepreneurial leadership, entrepreneurial leadership and differentiation strategy, cost leadership strategy and business performance, differentiation strategy and business performance, entrepreneurial mindset and business performance are meaningful (respectively; $\mathrm{p}=0.000, \mathrm{p}=0.000, \mathrm{p}=0.000, \mathrm{p}=0.007$ and $\mathrm{p}=0.001$ ). However, the relationships between entrepreneurial mindset and cost leadership, entrepreneurial mindset and differentiation strategy, entrepreneurial leadership and cost leadership strategy, and entrepreneurial leadership and business performance are meaningless (respectively; $\mathrm{p}=0.133, \mathrm{p}=0.553$, $\mathrm{p}=0.743$ and $\mathrm{p}=0.050$ ). For this reason, the meaningless relationships were removed from the model and improvements were made to the model.

As a result of the improvements made in the model, the relationships between entrepreneurial leadership and cost leadership, entrepreneurial leadership and business performance were found to be significant; so these relationships were not removed from the model. Also, the fit indices of the model shown in Figure 2 (CMIN/DF: 2.735; GFI: 0.923; AGFI: 0.892; NFI: 0.877; IFI: 0.919; TLI: 0.897; CFI: 0.918; RMSEA: 0.063; RMR: 0.078; SRMR: 0.0779) are within acceptable limits.

As a result of the improvements made on the model of the research, it has been observed that the entrepreneurial mindset has a positive effect on entrepreneurial leadership $(0.617 \mathrm{p}$ $<0.001$ ). In addition, entrepreneurial leadership has a positive and significant effect on cost 
leadership $(0.135 \mathrm{p}<0.05)$, differentiation strategies $(0.253 \mathrm{p}<0.001)$ and business performance $(0.173 \mathrm{p}<0.05)$. Upon examining the effects of cost leadership and differentiation strategies on business performance, we find out the existence of a negative impact of cost leadership strategy $(-0.308 \mathrm{p}<0.001)$ and a positive impact of differentiation strategy $(0.146$ $\mathrm{p}<0.05$ ) on business performance. Also, fit indices of model shown in Figure 3 (CMIN/DF: 2.705; GFI: 0.923; AGFI: 0.894; NFI: 0.877; IFI: 0.918; TLI: 0.899; CFI: 0.918; RMSEA: 0.062; RMR: 0.080; SRMR: 0.0796) are within acceptable limits.

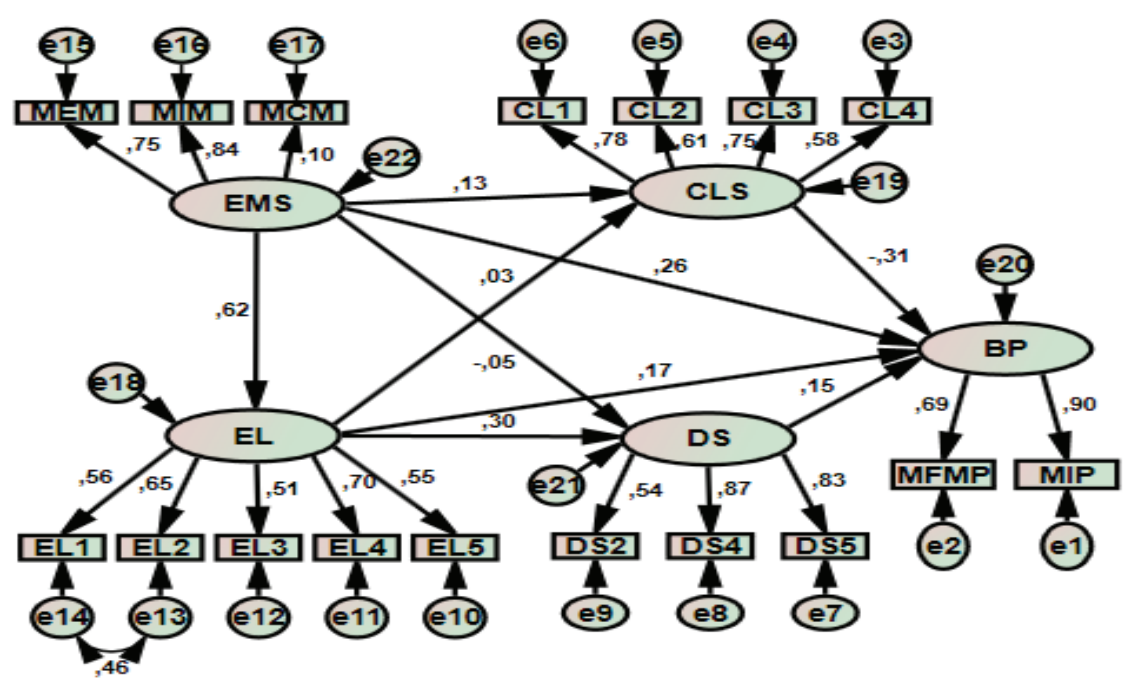

Figure 2. Standardized Estimation Results of the Structural Model

Table 2

Estimation Results of the Model

\begin{tabular}{llcccc}
\hline \multicolumn{2}{l}{ Variables } & Standardized Regression Weights & S.E. & C.R. & P \\
\hline EL & $<--$ EMS & 0.619 & 0.094 & 7.631 & $* * *$ \\
CLS & $<--$ EL & 0.029 & 0.093 & 0.327 & 0.743 \\
CLS & $<--$ EMS & 0.132 & 0.104 & 1.503 & 0.133 \\
DS & $<--$ EMS & -0.050 & 0.193 & -0.594 & 0.553 \\
DS & $<--$ EL & 0.303 & 0.182 & 3.315 & $* * *$ \\
BP & $<--$ CLS & -0.311 & 0.073 & -5.285 & $* * *$ \\
BP & $<--$ DS & 0.094 & 0.035 & 2.676 & 0.007 \\
BP & $<--$ EMS & 0.264 & 0.118 & 3.284 & 0.001 \\
BP & $<--$ EL & 0.169 & 0.110 & 1.962 & 0.050 \\
\hline
\end{tabular}

In the model, it has been revealed that entrepreneurial mindset has a positive and significant effect on entrepreneurial leadership $(0.619 ; \mathrm{p}<0.001)$ at $95 \%$ significance level. Also, as a result of the improvements made on the model (removing meaningless relationships), it has been observed that the entrepreneurial mindset has a positive effect on entrepreneurial 
leadership ( $0.617 ; \mathrm{p}<0.001)$. Therefore, $\mathrm{H} 1$ is supported. Besides, in the main model, it was determined that entrepreneurial mindset had a positive effect on business performance $(0.264$ $\mathrm{p}<0.001$ ). As a result of the improvements made to the model, it has been determined that the entrepreneurial mindset has a positive effect on business performance $(0.255 \mathrm{p}<0.001)$. Thus, $\mathrm{H} 2$ is supported. However, as seen in the research model, the entrepreneurial mindset of managers does not have a significant effect on cost leadership (0.132; $>0.05)$ and differentiation strategies $(-0.050 ; \mathrm{p}>0.05)$. According to these results, $\mathrm{H} 3$ and $\mathrm{H} 4$ are not supported.

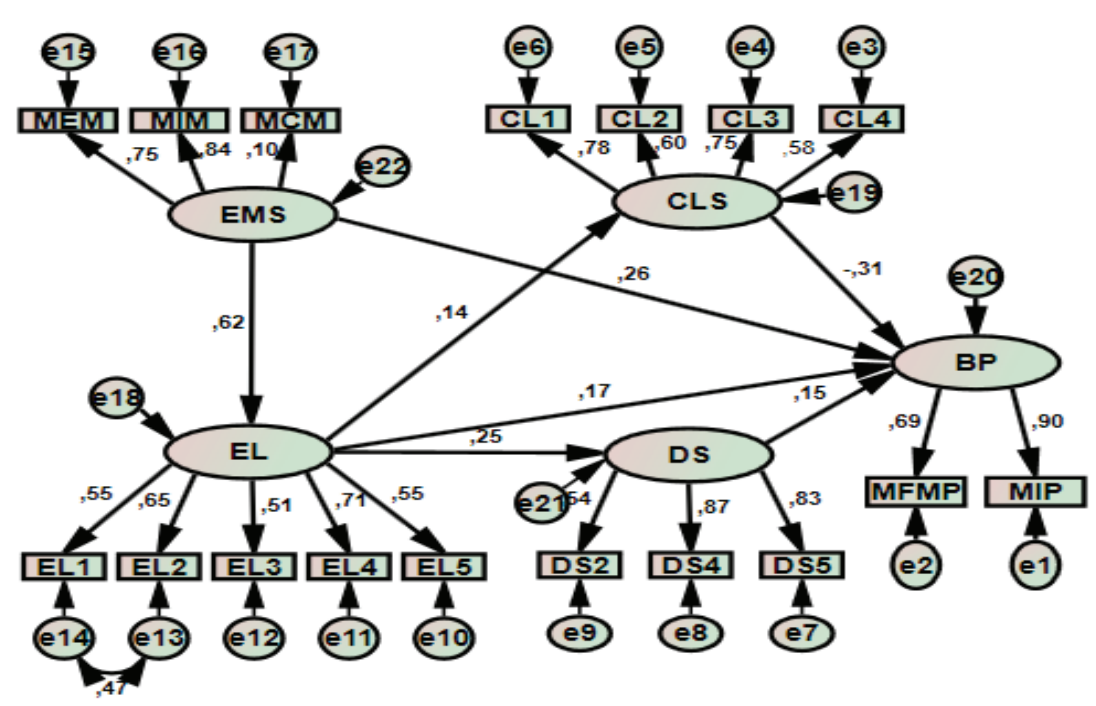

Figure 3. Standardized Estimation Results of The Improved Model

Table 3

Estimation Results of The Improved Model

\begin{tabular}{|c|c|c|c|c|c|}
\hline \multicolumn{2}{|c|}{ Variables } & \multirow{2}{*}{$\begin{array}{c}\text { Standardized Regression Weights } \\
0.617\end{array}$} & \multirow{2}{*}{$\begin{array}{r}\text { S.E. } \\
0.094\end{array}$} & \multirow{2}{*}{$\begin{array}{c}\text { C.R. } \\
7.648\end{array}$} & \multirow{2}{*}{$\begin{array}{c}\mathbf{P} \\
* * *\end{array}$} \\
\hline EL & $<---$ EMS & & & & \\
\hline CLS & $<---$ EL & 0.135 & 0.064 & 2.153 & 0.031 \\
\hline DS & <--- EL & 0.253 & 0.124 & 4.029 & $* * *$ \\
\hline $\mathrm{BP}$ & <--- CLS & -0.308 & 0.073 & -5.270 & $* * *$ \\
\hline $\mathrm{BP}$ & $<---$ DS & 0.146 & 0.035 & 2.716 & 0.007 \\
\hline $\mathrm{BP}$ & $<---$ EL & 0.173 & 0.108 & 2.043 & 0.041 \\
\hline $\mathrm{BP}$ & $<---$ EMS & 0.255 & 0.116 & 3.254 & 0.001 \\
\hline
\end{tabular}

In the main model, the entrepreneurial leadership did not have a significant effect on business performance $(0.169 ; \mathrm{p}=0.05)$, but as a result of improvements made by removing meaningless relationships, the entrepreneurial leadership has a positive and significant effect on 
business performance $(0.173 ; \mathrm{p}<0.05)$. Therefore, $\mathrm{H} 5$ which was rejected by the main model is supported by improvements. In the model, the entrepreneurial leadership has no significant effect on cost leadership ( $0.029 ; \mathrm{p}>0.05)$; however, as a result of the improvements made in the model, it is determined that entrepreneurial leadership has a positive effect on cost leadership $(0.135 ; \mathrm{p}<0.05)$.

H6 which was rejected in the main model is supported by improvements. Also, entrepreneurial leadership has been found to have a positive effect on differentiation strategies $(0.303$; $\mathrm{p}<0.001)$. Therefore, $\mathrm{H} 6$ is also supported.

In the main model, it was observed that cost leadership had a negative effect on business performance $(-0.311 ; \mathrm{p}<0.001)$. As a result of the improvements made on the model, the negative effect of the cost leadership on the business performance $(-0.308 ; p<0.001)$ has continued. According to these results, $\mathrm{H} 8$ is rejected. Similarly, it has been observed that the differentiation strategy variable has a positive and significant effect on business performance $(0.094 ; \mathrm{p}<0.05)$. As a result of the improvements made on the model, the positive effect of differentiation strategy on business performance $(0.146 ; p<0.05)$ has increased. Therefore, H9 is also supported. Moreover, the fact that cost leadership has a negative while differentiation strategy has a positive effect on business performance supports the view of Porter, who argues that these two strategies should not be used together.

\section{Conclusion}

In this research, entrepreneurship constructs such as entrepreneurial leadership and entrepreneurial mindset are combined with strategic constructs such as cost leadership and differentiation strategies, and the effect of these variables on business performance is examined. After reviewing the related literature, a model that shows how cost leadership and differentiation strategies affect the relationships among entrepreneurial mindset, entrepreneurial leadership, and business performance has been developed. Thus, we tried to present a model different from the existing strategic entrepreneurship models in the literature.

Our study focuses on two different views in the literature regarding cost leadership and differentiation strategies. Porter (1980-1985) believes that businesses need to choose and implement only one of the generic strategies (cost leadership and differentiation strategy) to improve their performance (Panwar et al., 2016: 579). On the other hand, Hill (1988) and Murray (1988) advocate that businesses can use cost leadership and differentiation strategies together. With the strategic entrepreneurship model designed in this research, we aimed to determine which view to support between Porter's and Hill and Murray's. To achieve this goal, the conceptual framework of the research was determined and the model of the research was tested. 
As a result of this research, when cost leadership and differentiation strategies are used together, cost leadership strategy affects business performance negatively while differentiation strategy affects business performance positively. These results support the opinion of Porter and other researchers (Linton and Helmet, who transferred from Miller, 2017: 170; Thornhill, 2007; Kumar, 1997; Josiah and Nyagara, 2015). Cost Leadership Strategy advocating reducing costs and differentiation strategy advocating innovation practices that increase costs may be conflicted with each other. In the analysis made on the sample data, the negative relationship between the cost leadership variable and the business performance variable supports this idea.

Before testing the hypotheses, the correlation relationship between the variables and the means of the variables were examined. The average of the variables of the study was examined and it was determined that the average of entrepreneurial leadership and entrepreneurial mindset was high. This research was conducted in medium-sized businesses, and their managers said they had a sufficient level of the entrepreneurial mindset and entrepreneurial leadership. In other words, the managers participating in the research see themselves as entrepreneurial leaders who are open to innovations, have a vision, and can take risks. Also, the analysis results showed that the cost leadership strategy has a higher average than the differentiation strategy. According to these results, it can be said that the business managers participating in the research prefer the cost leadership strategy more than the differentiation strategy. This may be because the differentiation strategy is costly. There is economic instability in Turkey and innovating is a costly strategy. For this reason, managers may have directed the implementation of the cost leadership strategy.

When the correlation relations between the variables are examined, it is seen that there is a positive and significant relationship between entrepreneurial leadership and cost leadership, entrepreneurial leadership and differentiation strategy, entrepreneurial leadership, and business performance. This situation shows us that entrepreneurial leaders are very important people for businesses. Nowadays, it is obvious that everything is changing rapidly and businesses that cannot adapt to change are disappearing. For this reason, there is a need for entrepreneurial leaders who are open to innovations and can think strategically. Especially medium-sized businesses need innovative, visionary, risk-taking, entrepreneurial, and brave managers to grow and make a profit.

Upon examining the corresponding literature, it was predicted that cost leadership and differentiation strategies may have an important role in the effect of entrepreneurial leadership and entrepreneurial mindset on business performance, and analyzes were made on the model developed based on this information. In the model, the entrepreneurial mindset is an independent variable; entrepreneurial leadership, cost leadership strategy, differentiation strategy, and business performance are considered as dependent variables. As a result of the analysis made on the research model, improvements have been made on the model since the relationships 
between entrepreneurial mindset and business performance, entrepreneurial mindset and cost leadership, entrepreneurial mindset, and differentiation strategy are meaningless. Analysis results were interpreted considering both the research model and the improved model results. As a result, the entrepreneurial mindset has positively affected both entrepreneurial leadership and business performance; however, it has no significant effect on differentiation and cost leadership strategies. Also, it has been determined that entrepreneurial leadership has a positive effect on business performance, cost leadership, and differentiation strategies. Although cost leadership negatively affects business performance; differentiation strategy positively affects business performance. One of the reasons that cost leadership negatively affects business performance may be innovation performance questions within the business performance scale.

Due to cost and availability, this research data was collected from a single city. Therefore, the sample of the research is limited to managers of medium-sized businesses in Erzurum. For this reason, it is recommended to conduct the research in different cities to generalize the study results. Also, it is suggested that other variables should be included in the research in order to evaluate the subject more comprehensively. In particular, environmental uncertainty, which is thought to have an impact on competitive strategies and performance, can be added to the model as an important variable.

Peer-review: Externally peer-reviewed.

Author Contributions: Conception/Design of study: G.E., A.N.; Data Acquisition: G.E., A.N.; Data Analysis/Interpretation: G.E., A.N.; Drafting Manuscript: G.E., A.N.; Critical Revision of Manuscript: G.E., A.N.; Final Approval and Accountability: G.E., A.N.

Conflict of Interest: The authors have no conflict of interest to declare.

Grant Support: The authors declared that this study has received no financial support.

\section{References}

Altuntas, G. (2014). Girişimcilik ve stratejik yönetim ilişkisi: Bir stratejik girişimcilik modeli ve testi. Istanbul Universitesi Isletme ve Yönetim Dergisi, 1(2), 103-129.

Antoncic, B., \& Hisrich, R D. (2004). Corporate entrepreneurship contingencies and organizational wealth creation. Journal of Management Development, 23(6), 518-550.

Bagheri, A. (2017). The impact of entrepreneurial leadership on innovation work behavior and opportunity recognition in high-technology SMEs. The Journal of High Technology Management Research, 28(2), 159-166.

Bagheri, A., \&Akbari, M. (2017). The impact of entrepreneurial leadership on nurses' innovation behavior. Journal of Nursing Scholarship. 50(1), 28-35.

Barney, J. B., \& Hesterly, W. S. (2012). Strategic Management And Competitive Advantage (Fourth Edition ed.). USA: Pearson.

Beal, R. M., \& Yasai-Ardekani, M. (2000). Performance implications of aligning CEO functional experiences with competitive strategies. Journal of Management, 26(4), 733-762. 
Bordean, O. N., Borza, A. I., Nistor, R. L., \& Mitra, C. S. (2010). The use of Michael Porter's generic strategies in the Romanian hotel industry. International Journal of Trade, Economics and Finance, 1(2), 173-178.

Chavez, R., Yu, W., Jacobs, M. A., \& Feng, M. (2017). Manufacturing capability and organizational performance: The role of entrepreneurial orientation. International Journal of Production Economics, 184, 33-46.

Chheda, K., \& Banga, C. (2013). Impact of entrepreneurial leadership on performance of small and medium enterprises in India. Journal of Asia Entrepreneurship and Sustainability, 9(2), 34-69.

Covin, J. G., \& Slevin, D. P. (1991). A conceptual model of entrepreneurship as firm behavior. Entrepreneurship: Critical perspectives on business and management, 3, 5-28.

Currie, G., Humphreys, M., Ucbasaran, D., \& McManus, S. (2008). Entrepreneurial leadership in the English public sector: paradox or possibility?. Public Administration, 86(4), 987-1008.

Çalık, M., Altunışık, R., \& Sütütemiz, N. (2013). Bütünleşik pazarlama iletişimi, marka performansı ve pazar performansı ilişkisinin incelenmesi. Uluslararası Yönetim İktisat ve İşletme Dergisi, 9(19), 137-161.

Daft, R. L. (2010). Management (9th ed.). United States: Thomson.

Darling, J. R., \& Beebe, S. A. (2007). Effective entrepreneurial communication in organization development: Achieving excellence based on leadership strategies and values. Organization Development Journal, 25(1), 76-93.

David, F., \& David, F. R. (2016). Strategic Management: A Competitive Advantage Approach, Concepts and Cases. USA: Pearson Education Sa Ebooks.

Dinçer, Ö. (2013). Stratejik Yönetim ve İşletme Politikası (9 ed.). İstanbul: Alfa.

Espino-Rodríguez, T. F., \& Lai, P. C. (2014). Activity outsourcing and competitive strategy in the hotel industry. The moderator role of asset specificity. International Journal of Hospitality Management, 42, 9-19.

Fontana, A., Fontana, A., Musa, S., \& Musa, S. (2017). The impact of entrepreneurial leadership on innovation management and its measurement validation. International Journal of Innovation Science, 9(1), 2-19.

Gupta, V., MacMillan, I. C, \& Surie, G. (2004). Entrepreneurial leadership: developing and measuring a cross-cultural construct. Journal of Business Venturing, 19(2), 241-260.

Hill, C. W. (1988). Differentiation versus low cost or differentiation and low cost: a contingency framework. Academy of Management Review, 13(3), 401-412.

Iqbal Sumaya, Mir Ajaz Akbar. (2018). Comparative analysis of business performance of insurance companies in Jammu and Kashmir on subjective performance measures. International Journal of Academic Research and Development, 3(1), 1253-1259.

Ireland, R. D., Hitt, M. A., \& Sirmon, D. G. (2003). A model of strategic entrepreneurship: The construct and its dimensions. Journal of Management, 29(6), 963-989.

Josiah, N., \& Nyagara, N. (2015). Assessment of the effect of Cost Leadership Strategy on the performance of Liquefied Petroleum Gas Companies in Eldoret town, Uasin Gishu County, Kenya. International Journal of Business and Management Invention, 4(4),1-7

Kavale, S., Mugambi, F., \& Namusonge, G. (2016). The effects of product differentiation strategy on corporate growth in selected microfinance institutions in Kenya. International Journal For Research In Business, Management And Accounting, 2(6), 13-28.

Keskin, H., Zehir, S., \& Ayar, H. (2016). Pazar yönelimi ve firma performansı ilişkisi: Farklılaştırma stratejisinin aracı rolü. Doğuş Universitesi Dergisi, 17 (1), 111-127.

Kesidou, E., \& Carter, S. (2014). Entrepreneurial leadership and firm performance: Reconciling the objective-subjective dichotomy. Rencontres St Gall, 9(1), 1-23. 
Kimuli, S. N. L. (2011). Strategic Entrepreneurship and Performance of Selected Private Secondary Schools in Wakiso District. (Doctoral dissertation, Makerere University).

Kriewall, T. J., \& Mekemson, K. (2010). Instilling the entrepreneurial mindset into engineering undergraduates. The journal of engineering entrepreneurship, 1(1), 5-19.

Kumar K., Subramanian, R., \& Yauger C. (1997). Pure versus hybrid: Performance implications of Porter's generic strategies. Health Care Management Review, 22(4), 47-61.

Kurtulus, K. (2006). Pazarlama Araştırmaları, Literatür Yayıncılık, Istanbul.

Lassen, A. H. (2007). Corporate entrepreneurship: an empirical study of the importance of strategic considerations in the creation of radical innovation. Managing Global Transitions, 5(2), 109-131.

Lee, C., Lee, K., \& Pennings, J. M. (2001). Internal capabilities, external networks, and performance: a study on technology-based ventures. Strategic management journal, 22(6-7), 615-640.

Leitch, C. M., \& Volery, T. (2017). "Entrepreneurial leadership: Insights and directions". International Small Business Journal, 35(2), 147-156.

Li, C. B., \& Li, J. J. (2008). Achieving superior financial performance in China: differentiation, cost leadership, or both?. Journal of International Marketing, 16(3), 1-22.

Ling, Y-H, \& Jaw, B-S. (2011). Entrepreneurial leadership, human capital management, and global competitiveness: An empirical study of Taiwanese MNCs. Journal of Chinese Human Resources Management, 2(2), 117-135.

Linton, G., \& Kask, J. (2017). Configurations of entrepreneurial orientation and competitive strategy for high performance. Journal of Business Research, 70, 168-176.

Liu, W., \& Atuahene-Gima, K. (2018). Enhancing product innovation performance in a dysfunctional competitive environment: The roles of competitive strategies and market-based assets. Industrial Marketing Management, 73(1), 7-20.

Mathisen, J-E, \& Arnulf, J. K. (2014). Entrepreneurial mindsets: Theoretical foundations and empirical properties of a mindset scale. The International Journal of Management and Business, 5(1), 81-101.

Martinez-Simarro, D., Devece, C., \& Llopis-Albert, C. (2015). How information systems strategy moderates the relationship between business strategy and performance. Journal of Business Research, 68(7), 15921594.

McGrath, R. G., \& MacMillan, I. C. (2000). The entrepreneurial mindset: Strategies for continuously creating opportunity in an age of uncertainty (284. bs): Harvard Business Press.

Mgeni, T. O., \& Nayak, P. (2015). Impacts of entrepreneurial leadership style on business performance of female owned SMEs in Dar es Salaam, Tanzania. Journal of Entrepreneurship and Management, 4(2), $39-50$.

Miles, G., Heppard, K. A., Miles, R. E., \& Snow, C. C. (2000). Entrepreneurial strategies. Entrepreneurship as strategy: Competing on the entrepreneurial edge, 101-114.

Murray, A. I. (1988). A contingency view of Porter's "generic strategies. Academy of management review, 13(3), 390-400.

Naktiyok, A. (2016). Endüstri ve Rekabet Analizi Stratejik Yönetim. Erzurum: Atatürk Üniversitesi AÖF.

Neneh, N. B. (2012). An exploratory study on entrepreneurial mindset in the small and medium enterprise (SME) sector: A South African perspective on fostering small and medium enterprise (SME) success. African Journal of Business Management, 6(9), 3364-3372. 
Newman, A., Neesham, C., Manville, G., \& Tse, H. H. (2017). Examining the influence of servant and entrepreneurial leadership on the work outcomes of employees in social enterprises. The International Journal of Human Resource Management, 1-22.

Newman, E. B. L. (2013). A theory on becoming an entrepreneurial leader: A student's developmental journey to a creation-driven mindset: (Ph. D. Thesis). University of Pennsylvania.

Njeru, P. W., Bwisa, H. M., \& Kihoro, J. M. (2012). Gender based entrepreneurial mind set and their influence on performance of small and medium manufacturing firms. International Journal of Business and Commerce, 1(9), 182-198.

Obeng, B. A., Robson, P., \& Haugh, H. (2014). Strategic entrepreneurship and small firm growth in Ghana. International Small Business Journal, 32(5), 501-524.

Ortega, M. J. R. (2010). Competitive strategies and firm performance: Technological capabilities' moderating roles. Journal of Business Research, 63(12), 1273-1281.

Phillips, L. W., Chang, D. R., \& Buzzell, R. D. (1983). Product quality, cost position and business performance: A test of some key hypotheses. The Journal of Marketing, 26-43.

Panwar, R., Nybakk, E., Hansen, E., P\& inkse, J. (2016). The effect of small firms' competitive strategies on their community and environmental engagement. Journal of Cleaner Production, 129, 578-585.

Rauch, A., Wiklund, J., Lumpkin, G. T., \& Frese, M. (2009). Entrepreneurial orientation and business performance: An assessment of past research and suggestions for the future. Entrepreneurship theory and practice, 33(3), 761-787.

Renko, M, El Tarabishy, A., Carsrud, A. L., \& Brännback, M. (2015). "Understanding and measuring entrepreneurial leadership style. Journal of Small Business Management, 53(1), 54-74.

Roomi, M. A., \& Harrison, P. (2011). Entrepreneurial leadership: What is it and how should it be taught?. International Review of Entrepreneurship, 9(3), 1-44).

Spanos, Y. E., Zaralis, G., \& Lioukas, S. (2004). Strategy and industry effects on profitability: Evidence from Greece. Strategic management journal, 25(2), 139-165.

Thornberry, N. (2006). Lead like an entrepreneur: Keeping the entrepreneurial spirit alive within the corporation. Fairfield, PA: McGraw Hill.

Thornhill S., \& White R.E. (2007). Strategic purity: A multi-industry evaluation of pure vs. hybrid business strategies. Strategic Management Journal, 28(5), 553-561.

Ward, P. T., \& Duray, R. (2000). Manufacturing strategy in context: environment, competitive strategy and manufacturing strategy. Journal of Operations Management, 18(2), 123-138.

Yamin, S., Gunasekaran, A., \& Mavondo, F. T. (1999). Relationship between generic strategies, competitive advantage and organizational performance: An empirical analysis. Technovation, 19(8), 507-518.

Yaşar, F. (2010). Competitive strategies and firm performance: Case study on Gaziantep carpeting sector/ Rekabet stratejileri ve firma performansi: Gaziantep hali sektörü üzerinde bir durum çalışması. Mustafa Kemal Üniversitesi Sosyal Bilimler Enstitüsü Dergisi, 7(14), 309-324.

Yücel, R., \& Ahmetoğulları, K. (2017). Rekabet stratejilerinin ileri imalat teknolojileri ve firma performans1 üzerine etkileri. AIBB̈̈IIIBF Ekonomik ve Sosyal Araştırmalar Dergisi, 12(2), 113-129.

Zahra, S. A., \& Garvis, D. M. (2000). "International corporate entrepreneurship and firm performance: The moderating effect of international environmental hostility". Journal of business venturing, 15(5), 469492.

Zehir, S. (2016). Pazar yonelimi, ogrenme yönelimi, rekabet stratejileri ve firma performansı ilişkisi. Gebze 
teknik universitesi sosyal bilimler enstitüsü. (Yayınlanmammış doktora tezi).

Zhang, Y. (2012). The impact of performance management system on employee performance-Analysis with WERS 2004. (Master's thesis), The University of Twente.

Zijlstra, P. (2014). When is entrepreneurial leadership most effective. (Master's thesis), University of Twente. 